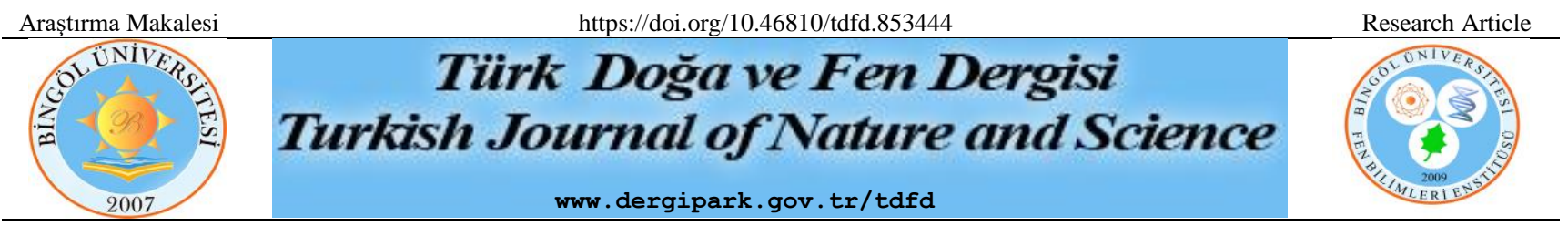

\title{
Makarnalık Buğday ve Tritikale Çeşitlerinde Hasat Zamanı ve Azotlu Gübre Uygulamasının Tane Verimi ile Bazı Kalite Özelliklerine Etkisi
}

\author{
İknur AKGÜN ${ }^{1}$, Esra ÖZBEK ${ }^{2}$, Aykut ŞENER ${ }^{3 *}$ \\ ${ }^{1}$ Isparta Uygulamalı Bilimler Üniversitesi, Ziraat Fakültesi, Tarla Bitkileri Bölümü, Isparta, Türkiye \\ ${ }^{2}$ Isparta Uygulamalı Bilimler Üniversitesi, Ziraat Fakültesi, Tarla Bitkileri Bölümü, Isparta, Türkiye \\ ${ }^{3}$ Isparta Uygulamalı Bilimler Üniversitesi, Ziraat Fakültesi, Tarla Bitkileri Bölümü, Isparta, Türkiye \\ İlknur AKGÜN ORCID No: 0000-0002-7476-7226 \\ Esra ÖZBEK ORCID No: 0000-0002-2147-9247 \\ Aykut ŞENER ORCID No: 0000-0003-1868-9451
}

*Sorumlu yazar: aykutsener@isparta.edu.tr

(Alınış: 04.01.2021, Kabul: 16.08.2021, Online Yayınlanma: 31.12.2021)

\begin{abstract}
Anahtar
Kelimeler

Firik,

Buğday,

Tritikale,

Azot,

Kalite,

Verim)
\end{abstract}

\begin{abstract}
Öz: $\mathrm{Bu}$ araştırmada, azotlu gübre uygulamalarının ve hasat zamanının tane verimi ve bazı kalite özelliklerine etkisi belirlenmiştir. Ayrıca, tritikalenin erken hasat edilerek firik olarak kullanılabilme olanağı araştırılmıştır. Araştırma, Bölünen Bölünmüş Parseller Deneme Desenine uygun olarak 3 tekerrürlü kurulmuştur. Ana parsellere çeşitler [2 makarnalık (Çeşit-1252 ve Kızıltan-91) ve 2 tritikale (Ümran Hanım ve Karma-2000) çeşidi], alt parsellere azotlu gübreler [NitroPower33 ve (yavaş salınımlı) Dinitroso], alt alt parsellere ise hasat zamanı [3 hasat zamanı (erken hamur olum, sert hamur olum ve tam olum)] yerleştirilmiştir. Araştırma sonuçlarına göre; nem oranı $(\% 13,92$ $42,29)$, protein oranı $(\% 13,99-16,90)$, kül oranı $(\% 1,48-1,61), 1000$-tane ağırlığı $(27,2-32,0 \mathrm{~g})$, hektolitre ağırlığı $(72,72-78,67 \mathrm{~kg})$ ve tane verimi $\left(173,05-287,47 \mathrm{~kg} \mathrm{da}^{-1}\right)$ üzerine hasat zamanının etkisinin istatistiksel olarak önemli olduğu belirlenmiştir. Olum döneminin ilerlemesine bağlı olarak tanenin nem ve protein oranı azalmasına karşın, kül oranı, 1000-tane ağırlığı, hektolitre ağırlığı ve tane verimi artmıştır. Farklı gübre uygulamalarının tanenin nem içeriğine, 1000-tane ağırlığına, hektolitre ağırlığına ve tane verimine etkisinin önemsiz; protein oranına (NP33: \%14.98 ve Dinitroso: \%16,50) ve kül oranına (NP33: \%1,50 ve Dinitroso: \%1,58) etkisinin ise önemli olduğu belirlenmiştir. Sonuç olarak, tritikalenin erken hasat edilerek firik amacıyla kullanılabileceği, makarnalık buğday ve tritikalenin firik amacıyla sert hamur olum döneminde hasat edilmesinin uygun olduğu belirlenmiştir.
\end{abstract}

\section{The Effect of Harvest Time and Nitrogen Fertilizer Application on Grain Yield and Some Quality Properties of Durum Wheat and Triticale Varieties}

\footnotetext{
Keywords

Freekeh,

Wheat,

Triticale,

Nitrogen,

Quality,

Yield
}

\begin{abstract}
In this study, the effects of nitrogenous fertilizer applications and harvest time on grain yield and some quality characteristics were determined. In addition, the possibility of early harvesting of triticale and using it as freekeh was investigated. The research was established in 3 replications in accordance with the Split-Split-Plot experimental design. Varieties [2 durum (Çeşit1252 and K1zıltan-91) and 2 triticale (Ümran Hanım and Karma-2000) varieties] were placed in the main plots, nitrogenous fertilizers (NitroPower33 and slow release Dinitroso) in the subplots, and harvest time (late milk, hard dough and ripe) in the sub-subplots. According to the research results, it was determined that the effect of cultivar and harvest time on moisture content $(13,92-42,29 \%)$, protein content $(13,99-16,90 \%)$, ash content $(1,48-1,61 \%)$, thousand grain weight $(27,2-32,0 \mathrm{~g})$, test weight $(72,72-78,67 \mathrm{~kg})$, grain yield $\left(173,05-287,47 \mathrm{~kg} \mathrm{da}^{-1}\right)$ was statistically significant. Although the moisture and protein ratio of the grain decreased due to the progress of the maturation period, the ash rate, thousand grain weight, test weight and grain yield increased. While the effect of different fertilizer applications on the moisture content of the grain, thousand grain weight, test weight and grain yield is not significant, the effect on protein ratio (NP33: 14,98\%and Dinitroso: 16,50\%) and ash ratio (NP33: 1,50\% and Dinitroso: 1,58\%) was determined to be significant.As a result, it has been determined that triticale can be used for freekeh with early harvest of triticale, durum wheat and triticale are harvested during the hard dough maturation period for freekeh.
\end{abstract}




\section{GİRIŞ}

Buğday, ülkemizde insan beslenmesindeki en temel besinlerin hammaddesi olması nedeniyle ekim alanı ve üretimde ilk sırada yer almaktadır. Türkiye'de buğday ekim alanı 6,8 milyon ha, üretimi yaklaşık 19 milyon ton olup, bunun yaklaşık 3,2 milyon tonunu makarnalık buğday oluşturmaktadır [1]. USDA [2] verilerine göre 2019/20 sezonunda Türkiye'nin buğday üretim tahminde bir önceki pazarlama yılına göre yaklaşık \%8'lik bir azalma olduğu bildirilmiştir. Son yıllarda yaşanan kuraklık ürün verimini ve kalitesini etkilemiştir. Bu nedenle bazı yıllarda buğdaya olan talep karşılanamamakta ve ithalat yapılmaktadır.

Artan nüfusun gıda gereksinimini karşılayabilmek için, bilim insanları marjinal alanlarda daha yüksek verim sağlayabilen alternatif ürünler üzerinde araştırmalarını yoğunlaştırmış ve buğdayın yanında alternatif olarak tritikalenin değerlendirileceğini bildirmişlerdir. Diğer tahıl cinsleri ile karşılaştırıldığında tritikalenin iklim değişikliklerine karşı daha kararlı olduğu, insan ve hayvan beslenmesi için daha iyi bir amino asit dengesine sahip olduğu bildirilmiştir $[3,4]$. Yine tritikale genotiplerinin buğdaydan daha yüksek besleme değerine ve hazmolunabilir protein oranına sahip olduğu ileri sürülmüştür [5]. Tritikalenin üretim miktarı Türkiye'de 215 bin ton olup, dekara verimi $336 \mathrm{~kg}$ 'dır [1].

Bitkilerin büyüme ve gelişmesinde en önemli besin maddelerinden birisi azot olup, en çok araştırılan konuların başında gelmektedir. Tahıllarda azot kullanım etkinliğinin \%33 olduğunu bildirilmiştir [6]. Bitkisel üretimde azot kullanım etkinliğini arttırmak için, son yıllarda yavaş salınımlı gübreler farklı bitkilerde araştırma konusu olarak incelenmektedir. Bu gübreler yavaş çözündükleri için etkinliği yüksek ve yıkanma kayıpları azdır. Toprakta değişime uğramadan, kil, kireç ve organik maddeye bağlanmaz, diğer elementlerle bileşik oluşturmaz. $\mathrm{Bu}$ nedenle yarayışsız forma geçmeden bitkiler tarafından kolayca alınır [7].

Buğday bazı bölgelerde geleneksel olarak farklı şekillerde kullanılmaktadır. $\mathrm{Bu}$ geleneksel gida ürünlerinin çoğu, Türkiye'nin diğer bölgelerinde iyi bilinmemektedir. $\mathrm{Bu}$ ürünlerden biri de firiktir. Firik olarak tanımlanan 1sıl işlem görmüş yeşil buğday (aynı zamanda frekeh veya freekah olarak da bilinir) Orta Doğu'da, Türkiye ve Avustralya gibi bazı ülkelerde yaygın olarak kullanılmaktadır. Bu ürünün kelimesi Arapça, afrakah'tan gelmektedir, olgun taneler eller arasında ovularak başaktan kolayca ayrılabilmektedir. Firik'in kendine özgü, tütsülenmiş bir tadı vardır. Firik için makarnalık buğday (Triticum durum) tercih edilir, ancak ekmeklik buğday (T. aestivum var. avestivum) da kullanılabilmektedir [8]. Tarih öncesi zamanlarda firik için diploid yabani buğday veya yabani siyez buğdayı $(T$. monococcum ssp. Baeoticum Boiss. Emend. E. Scheim) kullanılmıştır. Ortadoğu bölgesindeki bu gida maddesinin üretiminin yılda 200 ile 300 bin ton arasında olduğu bilinmektedir [9].
Bu çalışmada tritikalenin insan beslenmesinde alternatif değerlendirme amaciyla, erken hasat edilerek firik olarak kullanılabilme olanağı araştırılmıştır. Ayrıca son yıllarda gündeme gelen yavaş salınımlı gübre uygulamasının, makarnalık buğday ve tritikalede tane verimi ve kalitesine etkisi belirlenmiștir.

\section{MATERYAL VE METOT}

Bu araştırma 2018-2019 vejetasyon döneminde, Isparta Uygulamalı Bilimler Üniversitesi Ziraat Fakültesine ait deneme alanında yürütülmüştür. Araştırma, Bölünen Bölünmüş Parseller Deneme planına uygun olarak 3 tekerrürlü kurulmuştur. Denemede 4 çeşit (2 makarnalık (Çeşit-1252 ve Kızıltan-91) ve 2 tritikale (Ümran Hanım ve Karma-2000) çeşidi), 2 azotlu gübre çeşidi (NP33 ve Dinitroso) ve 3 hasat zamanı [Zadoks skalas1 8,3 erken hamur olum (1. hasat), 8,7 sert hamur olum (2. hasat) ve 9 tam olum (3. hasat)] faktör olarak incelenmiştir. Nitropower 33 (NP33); \%20 kükürt trioksit, \%25 üre, $\% 8$ amonyak, yavaş salınımlı (slow release) azotlu gübre Dinitroso: \%20,4 amonyum, \%0,6 disiyandiamid içermektedir.

Ana parsellere çeşitler, alt parsellere azotlu gübre, alt alt parsellere ise hasat zamanı yerleştirilmiştir. Kasım ayının ilk haftasında $\mathrm{m}^{2}$ ye 550 tohum düşecek şekilde ekim yapılmıştır. Parsel alanı 9,6 $\mathrm{m}^{2}$ (8 m x 1,2 m) olup, ekimle birlikte bütün parsellere dekara $7 \quad \mathrm{~kg} \quad \mathrm{P}_{2} \mathrm{O}_{5}$ hesabıyla fosforlu gübre uygulanmıştır. Azotlu gübreler içerisindeki azot oranına göre hesaplanarak toplam $10 \mathrm{~N}$ $\mathrm{kg} \mathrm{da}^{-1}$ olacak şekilde, yarısı ekimle birlikte $(5 \mathrm{~N} \mathrm{~kg} \mathrm{da}$ $\left.{ }^{1}\right)$, diğer yarısı ilkbaharda sapa kalkma başlangıcında parsellere $\left(5 \mathrm{~N} \mathrm{~kg} \mathrm{da}{ }^{-1}\right)$ verilmiştir. Yabancı ot mücadelesi $150-200 \mathrm{cc} \mathrm{da}^{-1}$ aktif madde hesabiyla 2,4-D terkipli herbisit kullanılmıştır.

Tane verimi, hasat alanı içerisindeki bitkiler harman edildikten sonra tartılmış ve elde edilen değerler dekara çevrilmiştir. Kjeldahl yöntemi ile azot içeriği belirlenmiş ve 6,25 katsayısı ile çarpılarak hesaplanmıştır [10]. Araştırmada bin tane ağırlığı (g), kül içeriği (\%) Yılmaz [11], ve hektolitre ağırlığı (kg) Elgün ve ark. [12] tarafından belirtilen esaslara göre yapılmıştır.

Araştırmada elde edilen sonuçlar Tesadüf Bloklarında Bölünen Bölünmüş Parseller deneme desenine göre TotemStat paket programlarından yararlanarak varyans analizine tabi tutulmuştur. Ortalamalar arasındaki farklılıkların istatistiki anlamda önemlilikleri Asgari Önemli Fark (AÖF) çoklu karşılaştırma testine göre yapılmıştır.

Araştırmanın yürütüldüğü 2018-2019 vejetasyon dönemine (Kasım-Haziran) ait sıcaklık $\left({ }^{\circ} \mathrm{C}\right)$ ve yağış (mm) değerleri Tablo 1'de verilmiştir. 2018-2019 üretim sezonunda yağış miktarı $(496,2 \mathrm{~mm})$ uzun yıllar ortalamasından $(500,2 \mathrm{~mm})$ daha düşük, ortalama sıcaklık ise daha yüksektir (uzun yillar sicaklık ortalaması $10,1{ }^{\circ} \mathrm{C}$; üretim sezonunda ortalama sicaklık $\left.10,8{ }^{0} \mathrm{C}\right)$. Yine üretim sezonundaki nispi nem oranı $(\% 55,6)$, uzun yıllar ortalamasından $(\% 64,2)$ daha düşüktür. 
Tablo 1. Denemenin yürütüldüğü yıl ve uzun yıllara (1929-2018) ait iklim verileri*

\begin{tabular}{|c|c|c|c|c|c|c|}
\hline \multirow{2}{*}{ Aylar } & \multicolumn{2}{|c|}{$\begin{array}{l}\text { Ort. Sicaklık } \\
\left({ }^{\circ} \mathrm{C}\right)\end{array}$} & \multicolumn{2}{|c|}{$\begin{array}{l}\text { Toplam Yağış } \\
(\mathbf{m m})\end{array}$} & \multicolumn{2}{|c|}{$\begin{array}{c}\text { Ort. Nispi Nem } \\
(\%)\end{array}$} \\
\hline & $\begin{array}{r}2018- \\
2019\end{array}$ & $\begin{array}{l}\text { Uz. Yil. } \\
\text { Ort. }\end{array}$ & $\begin{array}{l}2018- \\
2019\end{array}$ & $\begin{array}{l}\text { Uz. Yil. } \\
\text { Ort. }\end{array}$ & $\begin{array}{l}2018- \\
2019\end{array}$ & $\begin{array}{l}\text { Uz. Yıl. } \\
\text { Ort. }\end{array}$ \\
\hline Kasım & 9,1 & 7,8 & 48,6 & 45,2 & 67,7 & 70,0 \\
\hline Aralık & 3,5 & 3,5 & 107,1 & 87,5 & 82,7 & 75,8 \\
\hline Ocak & 2,5 & 1,8 & 97,0 & 80,8 & 81,3 & 75,2 \\
\hline Şubat & 4,5 & 2,9 & 55,4 & 68,1 & 72,1 & 71,6 \\
\hline Mart & 7,3 & 5,9 & 40,3 & 59,1 & 63,0 & 66,0 \\
\hline Nisan & 9,9 & 10,7 & 50,8 & 52,9 & 64,4 & 61,5 \\
\hline Mayıs & 16,8 & 15,4 & 34,2 & 56,7 & 53,4 & 59,2 \\
\hline Haziran & 20,7 & 19,8 & 53,3 & 33,6 & 59,8 & 52,5 \\
\hline Temmuz & 23,3 & 23,4 & 9,5 & 16,3 & 44,9 & 45,7 \\
\hline Ort./Top. & 10,8 & 10,1 & 496,2 & 500,2 & 55,6 & 64,2 \\
\hline
\end{tabular}

Deneme alanının 0-20 $\mathrm{cm}$ derinliğinden alınan toprak örneklerinin analiz sonuçlarına göre; toprağının strüktürü

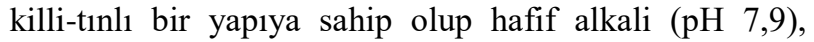
organik madde $(1,8)$, tuzsuz sınıf toprak, kireç oranı\%32,4, fosfor bakımından düşük $\left(7,2 \mathrm{~kg} \mathrm{da}^{-1}\right)$, potasyum $\left(176,2 \mathrm{~kg} \mathrm{da}^{-1}\right)$ bakımından ise yeterli seviyeye sahiptir.

\section{BULGULAR}

\subsection{Nem Oranı}

Araştırmada farklı hasat dönemlerinin tanedeki nem oranına etkisi istatistiksel olarak önemli bulunmuştur $(\mathrm{P} \leq 0,01)$. Çeşidin ve azotlu gübrenin etkisi önemsiz bulunmuştur. Çeşidin etkisinin önemsiz olması, hasatın (Zadoks skalasına göre 8,3 erken hamur olum, 8,7 sert hamur olum ve 9 tam olum) tüm çeşitlerde benzer dönemlerinde yapıldığını ve tanedeki nem içeriği yönünden çeşitler arasında farklılığın olmadığını göstermektedir. Firik elde etmek amacıyla hasatta doğru zamanı belirlemek kritik öneme sahiptir. Eğer taneler çok erken hasat edilir ve kavrulursa, taneler çok küçülmekte, çok geç hasat edilirse firikin kendine özgü yeşil rengini ve lezzetini kaybetmesine neden olmaktadır.

Araştırmada genel ortalama olarak tanedeki nem içeriği tam olgunlaşma döneminde önemli seviyede azalmıştır $(\% 13,92)$. Erken hamur döneminde tanedeki nem içeriği $\% 42,29$, sert hamur olum döneminde ise \%19,04 olarak belirlenmiştir (Tablo 2).

Tablo 2. Farklı dönemlerinde hasat edilen ve azotlu gübre uygulanan makarnalık buğday ve tritikale çeşitlerinin tanedeki nem oranına (\%) ilişkin ortalamalar

\begin{tabular}{|c|c|c|c|c|c|c|c|c|c|}
\hline \multirow{2}{*}{ Çeşit/ Hasat zamanı } & \multicolumn{3}{|c|}{ 1. Hasat } & \multicolumn{3}{|c|}{ 2. Hasat } & \multicolumn{3}{|c|}{ 3. Hasat } \\
\hline & NP33 & Dinitroso & Ort. & NP33 & Dinitroso & Ort. & NP33 & Dinitroso & Ort. \\
\hline Ç-1252 & 41,33 & 41,33 & 41,333 & 18,33 & 18,67 & 18,50 & 13,67 & 14,00 & 13,83 \\
\hline Kızıltan-91 & 40,67 & 43,67 & 42,167 & 20,33 & 19,33 & 19,83 & 14,00 & 14,00 & 14,00 \\
\hline Ümran Hanım & 41,33 & 40,33 & 40,833 & 18,67 & 18,67 & 18,67 & 13,67 & 14,00 & 13,83 \\
\hline Karma-2000 & 44,33 & 45,33 & 44,833 & 19,00 & 19,33 & 19,17 & 14,00 & 14,00 & 14,00 \\
\hline Ortalama & 41,92 & 42,67 & $42,29 \mathrm{~A}^{1}$ & 19,08 & 19,00 & 19,04 B & 13,83 & 14,00 & $13,92 C$ \\
\hline
\end{tabular}

$\mathrm{Bu}$ konuda yapılan çalışmalar incelendiğinde farklı sonuçlar bulunmuştur. Nitekim Carsanba et al. [13], Hatay yöresinden toplamış olduğu 4 farklı firik örneğinde nem oranını $\% 10,0-11$ arasında değiştiğini bildirilmiştir. Hamit ve Omari [14] tarafından yapılan çalışmada nem içeriği \%8-10,2 arasında değişmiştir. Yeşil buğday olarak tanımlanan firik, dolgun, hafif tatlı ve çiğnenebilir özellikte olduğu ifade edilmektedir. Ayrıca yüksek nem içeriğine sahip olup kurutulduğunda ağırlığının yaklaşık \%40'1 kaybettiği ifade edilmektedir [15, 9]. Buna göre araştırmada 2. hasat döneminde çeşitlere göre \%19-20 arasında olan nem içeriğinin \%40 kaybolduğu kabul edilirse, firik olarak tanedeki nem içeriği \%11-12 arasında değişecektir. $\mathrm{Bu}$ dönemdeki hasattan elde edilen firik için nem değerleri literatür bilgileri ile uygunluk göstermektedir.
Olgunlaşma esnasında tane içeriğindeki değișiklikler firik özelliklerini etkileyebilecektir. Firik işlemleri için kabul edilebilir süreçler için buğdayın geç süt olumorta hamur olum dönemleri arasında hasat edilmesi önerilmiştir [16, 17]. Yine tane boyutlarının nem içeriği ile ilişkili olduğu ve tane boyutunun da mekanizasyon işlemlerini etkilediği bildirilmiştir [18].

\subsection{Protein Oranı $(\%)$}

Tablo 3 incelendiğinde, 1 . ve 2 . hasat döneminde tanedeki protein oranı sirasıly $\% 16,34$ ve $\% 16,90$ olarak belirlenmiş ve arasındaki farklılık önemli bulunmamıștır. Tam olum dönemde tanedeki protein oranı önemli seviyede azalmıştır $(\% 13,99)$. Erken hasat dönemlerinde tanedeki protein içeriği daha yüksektir. Olgunlaşmaya bağlı olarak tanede nişasta birikiminin artması, protein oranını azaltmıştır. 
Tablo 3. Farklı dönemlerinde hasat edilen ve azotlu gübre uygulanan makarnalık buğday ve tritikale çeșitlerinin tanedeki protein oranına (\%) ilișkin ortalamalar

\begin{tabular}{|c|c|c|c|c|c|c|c|c|c|}
\hline \multirow{2}{*}{ Çeşit/ Hasat zamanı } & \multicolumn{3}{|c|}{ 1. Hasat } & \multicolumn{3}{|c|}{ 2. Hasat } & \multicolumn{3}{|c|}{ 3. Hasat } \\
\hline & NP33 & Dinitroso & Ort. & NP33 & Dinitroso & Ort. & NP33 & Dinitroso & Ort. \\
\hline Ç-1252 & 13,71 & 16,21 & 14,96 & 16,20 & 17,62 & 16,91 & 12,05 & 13,64 & 12,84 \\
\hline Kızıltan-91 & 14,35 & 17,41 & 15,88 & 15,94 & 17,76 & 16,85 & 13,33 & 14,54 & 13,93 \\
\hline Ümran Hanım & 16,75 & 17,31 & 17,03 & 16,42 & 17,49 & 16,96 & 13,45 & 15,66 & 14,56 \\
\hline Karma-2000 & 17,40 & 17,54 & 17,47 & 15,92 & 17,88 & 16,90 & 14,26 & 14,97 & 14,62 \\
\hline Ortalama & 15,55 & 17,12 & $16,34 A^{1}$ & 16,12 & 17,69 & $16,90 \mathrm{~A}$ & 13,27 & 14,70 & $13,99 B$ \\
\hline
\end{tabular}

Genel ortalama olarak protein oranı, yavaș salınımlı (Dinitroso) gübre uygulamasinda $(\% 16,50) \quad$ NP33 uygulamasına $(\% 14,98)$ göre daha yüksek bulunmuş ve bu farklılık istatistiksel olarak önemli olmuştur (Tablo 3). Çeşit $\mathrm{x}$ gübre interaksiyonuna ait ortalama protein oranları Tablo 4' de verilmiştir.

Tablo 4. Makarnalık buğday ve tritikale çeșitlerinde protein oranına (\%) ilişkin çeşit x gübre interaksiyonuna ait ortalamalar

\begin{tabular}{lccc}
\hline Çeşit/Gübre & NP33 & Dinitroso & Ortalama \\
\hline Çeşit-1252 & 13,98 & 15,82 & 14,90 \\
Kızıltan-91 & 14,54 & 16,57 & 15,55 \\
Ümran Hanım & 15,54 & 16,82 & 16,18 \\
Karma-2000 & 15,86 & 16,79 & 16,33 \\
\hline Ortalama & $\mathbf{1 4 , 9 8 ~ \mathbf { B } ^ { \mathbf { 1 } }}$ & $\mathbf{1 6 , 5 0 ~ A}$ & \\
\hline \multicolumn{1}{c}{ LSD $_{\text {(gübre) }}$} & $\mathbf{0 , 3 5 9}$ & \\
\hline${ }^{1}$ Aynı satırda farklı harfle gösterilen ortalamalar arasındaki fark \\
önemlidir.
\end{tabular}

Tablo 4'de yavaş salınımlı azotlu (Dinitroso) gübre uygulamasında en yüksek protein oranı \%16,82 ile Ümran Hanım çeşidinden elde edilirken. en düşük protein oranı \%15,82 ile Çeşit-1252 çeşidinde belirlenmiştir. NP33 uygulamasında ise en yüksek protein oranı Karma-2000 (\%15,86), en düşük protein oranı ise \%13,98 ile Çeşit-1252 çeşitlerinde tespit edilmiştir. Ancak gübre uygulamasına çeşitlerin tepkisi farklı olmasına rağmen, çeşit $\mathrm{x}$ gübre interaksiyonu önemli bulunmamıştır. Dinitroso gübre uygulamasında hem makarnalık hem de tritikale çeşitlerine protein oranı daha yüksektir. Araştırma sonucuna göre yavaş salınımlı azotlu gübre (Dinitroso) uygulamasında çeşitlerin azotu kullanabilme süresinin uzadığı ya da bitkiler tarafından alınabilirliğinin daha fazla olduğu söylenebilir. Yavaş salınımlı gübrelerin vejetasyon periyodu süresince diğer gübrelere oranla daha üniform bir büyüme ve gelişme ortamı sağladığı ileri sürülmüştür [19].

Protein oranı, çeşitlere göre farklılık göstermiş (\%14,90-16,33) ancak bu farklılık istatistiksel olarak önemli bulunmamıştır (Tablo 4). Sayısal olarak en yüksek protein oranı tritikale çeşitlerinde (Ümran Hanım \%16,18; Karma-2000 \% 16,33) belirlenmiştir.

$\mathrm{Bu}$ konuda yapılan araştırmalarda tritikalede protein oran1; Feil and Fossati [20] \%9,6 - 12,2, Atak ve Çiftçi [21] Ankara koşullarında \%11,9-14,37 arasında, Akgün ve ark. [22] Isparta ekolojik koşullarında \%10,3-12,7 arasında değiştiğini bildirmişlerdir.
Araştırmada çeşitlerin azot kullanım etkinliğine bağ ${ }_{1}$ olarak, hasat dönmelerinde protein oranları değişmiştir. Tahıllarda azotlu gübre miktarı, formu ve verilme zamanı verimi belirlemede en etkin faktörlerden birisidir. Haile et al. [23] tarafindan ekmeklik buğday üzerinde yapılan çalışmada, azotun uygulanma zamanı ve dozu tane protein oranı ve tane verimi üzerine önemli derecede etkili olduğu, ancak çeşitlere göre azot kullanım etkinliğinin değiştiği belirlenmiştir. Araştırmada tanedeki protein oranının \%12,40-13,09 arasında değiştiği bildirilmiştir. Akgün ve Ulupınar [ 24] tarafından farklı makarnalık buğday çeşitleri kullanılarak yapılan çalışmada, iki yıllık ortalama sonuca göre Çeşit-1252 ve Kızıltan-91 çeşitlerinin protein oranı sirasiyla $\% 13,0$ ve $\% 13,18$ olarak belirlenmiştir. Her iki çeşitte de $10 \mathrm{~kg} / \mathrm{da}$ azotun üzerinde protein oranında önemli bir farklılık belirlenmemiştir.

Yavaş salınımlı gübrelerde toprak nemi ve sicaklığı, mikrobial aktivite, gibi faktörlere bağlı olarak azotun salınımı değişebilmektedir [25]. Yavaş ayrışan gübrelerin daha kullanılabilir bir azot kaynağı ve amonyum nitrat gübresine oranla nitrat kayıplarının daha az olduğunu bildirilmiştir [26]. Yine verimi arttırmak ve ekolojik dengeyi korumak açısından en uygun uygulamanın düşük dozdaki yavaş ayrışan gübreler olduğunu ifade edilmiştir [27, 28]. Farklı bir çalışmada yavaş ayrışan gübrelerin uygulandığ topraklarda N/P oranı daha yüksek olduğu ve buğdayın tane protein içeriğini \%2,9 artırdığı bildirilmiştir [29].

Yaptığımız bu çalışmada, yavaş salınımlı gübre tüm çeşitlerde protein oranını arttırmıştır. $\mathrm{Bu}$ sonuçlar yavaş salınımlı gübrelerin bitki gelişmesinde daha etkin olduğunu göstermektedir. Son zamanlarda özellikle sağlık açısından birçok yararı bildirilen firik buğdayı, yeşil buğday olarak da adlandırılmakta ve geleneksel bir gida olarak tanımlanmaktadır [30, 31]. Bu konuda yapılan çalışmalarda ısıl işlem görmüş yeşil buğdayın besin değerinin. \%12.7 protein ile pirinç ve bulgurdan üstün olduğu ileri sürülmüştür [32]. Yine hasat zamanının firik kalitesi üzerindeki etkisi araştırılmış [14] ve erken dönemde yapılan hasatlarda daha yüksek protein içeriği belirlenmiştir. Ozkaya et al. [17] tarafından yapılan araştırmada çiçeklenmeden tam oluma kadar geçen sürelerde (3 gün aralıklarla 6 örnekleme) firik amaciyla alınan buğday örneklerinde protein içeriği olgunlaşma zamanı ilerledikçe azalmıştır. 
Carsanba et al. [13] pirinç, bulgur ve firik'in besin elementi içeriğiyle ilgili yaptıkları bir çalışmada, firikin protein oranını \%11,44 olarak bulmuşlardır. Makarnalık buğday kullanılarak yapılan çalışmalarda protein içeriği; Aydın ve ark. [33] \%8,1-13,6, Budak ve Karaltın [34] \%9,5-13,5 arasında değiştiği belirlenmiștir.

Sonuç olarak, önemli kalite kriterlerden birisi olan protein oranı yönünden tritikalenin erken hasat edilerek (sert hamur olum), firik olarak kullanılabileceği düşünülmektedir.

\subsection{Kül Oranı}

Kül oranı üzerine çeşidin, gübre uygulamasının ve hasat zamanının etkisi önemli bulunmuştur $(\mathrm{P} \leq 0,01)$. En yüksek kül oranı \%1,61 ile tam olum döneminde, en düşük ise 2. hasatta belirlenmiş $(\% 1,48)$ ve hasat zamanları istatistiksel olarak farklı grupta yer almıştır. Çeşitlerin kül oranı hasat zamanlarına göre farklı olduğundan, çeşit $\mathrm{x}$ hasat interaksiyonu istatistiksel olarak önemli olmuştur (Tablo 5). Nitekim erken hamur olum dönemini tanımlayan 1. hasatta en yüksek kül oranı Ümran Hanım çeşidinde $(\% 1,72)$ belirlenmiş, bu çeşit ile diğerleri arasındaki fark önemli olmuştur. İkinci hasat döneminde tritikale çeşitlerinde kül oranı makarnalık buğday çeşitlerinden daha yüksek olduğu (Ümran Hanım \%1,56; Karma-2000 \%1,59) belirlenmiştir. Tam olum döneminde ise kül oranı yönünden Çeşit-1252 $(\% 1,36)$ hariç, diğer çeşitler istatistiksel olarak aynı grupta yer almıştır (Tablo 5). Bin tane ağırlığı ve hektolitre ağırlığ 1 değerleri incelendiğinde, tritikale çeşitlerinde tane dolgunluğunun Çeşit-1252 den az olduğu belirlenmiştir (Tablo 8 ve 10). Bu durum tane dolgunluğunun kül oranı ile ilişkili olabileceğini göstermektedir. Yine küçük tane oranı arttıkça un veriminin azaldığı ve kül miktarının arttığı bildirilmiştir [35]. Ayrıca kül içeriğinin özellikle olgunlaşma dönemindeki iklim koşullarına [36], çeşitlere ve gübrelemeye göre değiştiği, artan azot dozunun kül içeriğini azalttığ 1 bildirilmiştir [37].

Tablo 5. Farklı dönemlerinde hasat edilen ve azotlu gübre uygulanan makarnalık buğday ve tritikale çeşitlerinin kül oranına (\%) ait ortalamalar

\begin{tabular}{|c|c|c|c|c|c|c|c|c|c|}
\hline \multirow{2}{*}{ Çeşit/ Hasat zamanı } & \multicolumn{3}{|c|}{ 1. Hasat } & \multicolumn{3}{|c|}{ 2. Hasat } & \multicolumn{3}{|c|}{ 3. Hasat } \\
\hline & NP33 & Dinitroso & Ort. & NP33 & Dinitroso & Ort. & NP33 & Dinitroso & Ort. \\
\hline Çeşit-1252 & 1,39 & 1,58 & $1,48 b^{1}$ & 1,32 & 1,36 & $1,34 \mathrm{~b}$ & 1,36 & 1,37 & $1,36 \mathrm{~b}$ \\
\hline Kızıltan-91 & 1,34 & 1,47 & $1,41 \mathrm{~b}$ & 1,40 & 1,46 & $1,43 \mathrm{~b}$ & 1,66 & 1,67 & $1,67 \mathrm{a}$ \\
\hline Ümran Hanım & 1,69 & 1,75 & $1,72 \mathrm{a}$ & 1,44 & 1,67 & $1,56 \mathrm{a}$ & 1,64 & 1,81 & $1,73 \mathrm{a}$ \\
\hline Karma-2000 & 1,50 & 1,52 & $1,51 b$ & 1,56 & 1,62 & $1,59 \mathrm{a}$ & 1,71 & 1,66 & $1,68 \mathrm{a}$ \\
\hline Ortalama & 1,48 & 1,58 & $1,53 \mathrm{~B}^{2}$ & 1,43 & 1,53 & $1,48 \mathrm{C}$ & 1,59 & 1,63 & $1,61 \mathrm{~A}$ \\
\hline
\end{tabular}

Araştırmada tam olum döneminde en yüksek kül oranı belirlenmiştir. Ancak Hamit and Omari [14] erken dönemde yapılan hasatlarda daha yüksek kül oranı bulunduğunu, Ozkaya et al. [17] tohum olgunlaşmasına bağlı olarak firik buğday örneklerinde kül oranının azaldığını bildirmişlerdir. Farklı sonuçların bulunması iklim şartları, kullanılan çeşitlerden ve gübre uygulamalarından kaynaklandığı düşünülmektedir.

Araştırmada kullanılan gübrelere göre kül oranı, NP33 uygulamasında \%1,50 Dinitroso uygulamasinda ise $\% 1,58$ olarak belirlenmiş ve bu değerler arasındaki fark istatistiksel olarak önemli olmamıştır. Tüm hasat seviyelerinde hem makarnalık hem de tritikale çeşitlerinde yavaş salınımlı azotlu gübre uygulamasında (Dinitroso) kül oranı daha yüksek bulunmuştur. Her iki gübre formunda da tritikale çeşitlerinin kül oranı daha fazla ve çeşitler arasındaki farkın önemli olduğu belirlenmiştir. Kül oranı en yüksek Ümran Hanım $(\% 1,67)$, en düşük ise Çeşit$1252(\% 1,40)$ çeşitlerinde tespit edilmiştir (Tablo 6).

Kül miktarı, buğdayın un kalitesini belirlemede önemli bir faktör olup özellikle undaki kepek miktarına göre değişmektedir. Kül miktarı buğday tanesindeki mineral madde zenginliği ile ilişkili olup, çeşit özelliklerinden ve farklı yetiştirme uygulamalarından etkilenmektedir [38]. Kül miktarı ve bileşimi, buğday bitkisinin yetiştiği topraktaki mineral madde miktarına ve alınabilirliğine bağlı olarak değişmektedir. Ülkemizdeki buğdaylarda kül oranının \%0,8-1 arasında olduğu bildirilmiştir [39]. Yine kül içeriğinin iklim, çeşit ve gübrelemeye göre farklılaştığı ayrıca azotlu gübrelemenin kül içeriğini azalttığı ileri sürülmüştür [35]. İyi bir ekmeklik kalitesi için undaki kül miktarının \%1,3-2,5 arasında olması gerektiği bildirilmiştir [40].

Tablo 6. Makarnalık buğday ve tritikale çeşitlerinde kül oranına (\%) ilişkin çeşit $\mathrm{x}$ gübre interaksiyonuna ait ortalamalar

\begin{tabular}{|c|c|c|c|}
\hline Çeşit/Gübre & NP33 & Dinitroso & Ortalama \\
\hline Çeşit-1252 & 1,35 & 1,44 & $1,40 \mathrm{D}^{1}$ \\
\hline Kızıltan-91 & 1,47 & 1,53 & $1,50 \mathrm{C}$ \\
\hline Ümran Hanım & 1,59 & 1,75 & $1,67 \mathrm{~A}$ \\
\hline Karma-2000 & 1,59 & 1,59 & $1,59 \mathrm{~B}$ \\
\hline Ortalama & $1,50 \mathrm{~B}^{1}$ & $1,58 \mathrm{~A}$ & \\
\hline \multicolumn{4}{|c|}{$\mathbf{L S D}_{\text {(gübre) }}: 0,041 ; \mathbf{L S D}_{\text {(ceşit) }}: 0,070$} \\
\hline
\end{tabular}

$\mathrm{Bu}$ konu ile ilgili yapılan çalışmalarda tritikale tanesindeki kül oranı; Leon et al. [41] \%0,9-3,0, Mut ve Köse [42] \%1,68- 2,17; buğday ununda kül miktarının Haghayegh ve Schoenlechner [43] \%1,88; Yaraşır [44] buğday tanesinde \%1,22-1,51 arasında 
değiştiği rapor edilmiştir. Ham kül oranı çeşide, iklim ve toprak koşullarına, kültürel uygulamalara göre değiş̧ebildiğinden [36], çalışmalarda farklı sonuçlar elde edilmiştir. Nitekim Misra et al. [36] makarnalık buğday çeşitlerinde tanedeki kül içeriğinin yıllara göre değişiklik gösterdiğini bildirmiștir (1. y1l \%1,4-1,7, 2. yıl \%1,3-1,5). Araştırıcılar kül içeriğinin özellikle olgunlaşma dönemindeki iklim koşullarına [36], çeşitlere ve gübrelemeye göre değiştiği, artan azot dozunun kül içeriğini azalttığı bildirilmiștir [45, 37]. Diğer taraftan Aksu [46], ekmeklik buğday çeşitlerinde kül oranlarının \%1,457-1,553 arasında değiştiğini ve artan azot dozlarının kül oranını önemli seviyede arttırdığını tespit etmiştir. Dexter et al. [47] durum buğday çeşitlerinde azotlu gübrelemeye bağlı olarak kül miktarlarının \%1,57-1,49 arasında değiştiğini bildirmiştir. Carsanba et al. [13] firik buğday örneğinde kül oranını \%1,86 olarak tespit etmişlerdir. Ozkaya et al. [17] tarafindan yapılan çalıșmada çeşitlere göre kül oranı \%1,57-2,61 arasında değişmiştir.

\subsection{Bin Tane Ăğırlığı}

Araştırmada bin tane ağırlığı üzerine çeşidin ve farklı hasat dönemlerinin etkisi istatistiksel olarak önemli bulunmuştur $(\mathrm{P} \leq 0,01)$. Ortalama bin tane ağırlığ 1 . hasat döneminde $27,2 \mathrm{~g}, 2$. hasat döneminde $29,6 \mathrm{~g}, 3$. hasat döneminde ise $32,0 \mathrm{~g}$ olarak belirlenmiştir (Tablo 7). Tüm çeşitlerde olgunlaşmanın ilerlemesine bağlı olarak tanedeki nișasta birikiminin artması, bin tane ağırlı̆̆ını arttırmış ve çeşit $\mathrm{x}$ hasat interaksiyonu önemli bulunmamıștır.

Tablo 7. Farklı dönemlerinde hasat edilen ve azotlu gübre uygulanan makarnalık buğday ve tritikale çeşitlerinin bin tane ağırlığına (g) ilişkin ortalamalar

\begin{tabular}{|c|c|c|c|c|c|c|c|c|c|}
\hline \multirow{2}{*}{ Çeşit/ Hasat zamanı } & \multicolumn{3}{|c|}{ 1. Hasat } & \multicolumn{3}{|c|}{ 2. Hasat } & \multicolumn{3}{|c|}{ 3. Hasat } \\
\hline & NP33 & Dinitroso & Ort. & NP33 & Dinit. & Ort. & NP33 & Dinit. & Ort. \\
\hline Ç-1252 & 32,33 & 28,67 & 30,50 & 33,33 & 32,00 & 32,67 & 35,67 & 34,00 & 34,83 \\
\hline Kızıltan-91 & 26,00 & 26,67 & 26,33 & 28,33 & 32,67 & 30,50 & 31,33 & 35,00 & 33,17 \\
\hline Ümran Hanım & 25,00 & 26,00 & 25,50 & 26,333 & 27,67 & 27,00 & 29,33 & 30,00 & 29,67 \\
\hline Karma-2000 & 27,67 & 25,33 & 26,50 & 29,67 & 27,00 & 28,33 & 31,33 & 29,33 & 30,33 \\
\hline Ortalama & 27,75 & 26,67 & $27,2 C^{1}$ & 29,42 & 29,83 & $29,6 \mathrm{~B}$ & 31,92 & 32,08 & $32,0 \mathrm{~A}$ \\
\hline
\end{tabular}

Araştırmada çeşitlerin gübre kullanım etkinliği farklı olduğundan, çeşit $\mathrm{x}$ gübre interaksiyonu önemli bulunmuştur (Tablo 8).

Tablo 8. Makarnalık buğday ve tritikale çeşitlerinde bin tane ağırlığına (g) ilişkin çeşit $\mathrm{x}$ gübre interaksiyonuna ait ortalamalar

\begin{tabular}{lccc}
\hline Çeşit/Gübre & NP33 & Dinitroso & Ortalama \\
\hline Çeşit-1252 & $33,78 \mathrm{~A} *$ & $31,56 \mathrm{~A}$ & $32,67 \mathrm{~A}$ \\
Kızıltan-91 & $28,56 \mathrm{BC}$ & $31,44 \mathrm{~A}$ & $30,00 \mathrm{~B}$ \\
Ümran Hanım & $26,89 \mathrm{C}$ & $27,89 \mathrm{~B}$ & $27,39 \mathrm{C}$ \\
Karma-2000 & $29,56 \mathrm{~B}$ & $27,22 \mathrm{~B}$ & $28,39 \mathrm{BC}$ \\
\hline Ortalama & 29,69 & 29,53 &
\end{tabular}

\begin{tabular}{lc}
\hline Ortalama & 29,69 \\
\hline LSD $_{\text {(essit x gübre): }} \mathbf{2 , 0 3 0} ; \mathbf{L S D}_{\text {(cesit): }} \mathbf{1 , 9 6 4}$
\end{tabular}

*Aynı sütunda aynı harfle verilen ortalamalar arasındaki fark önemli değildir.

NP33 gübre uygulamasında en yüksek bin tane ağırlığg 33,78 g ile Çeşit-1252 çeşidinden elde edilmiş ve diğer çeşitler ile arasındaki fark önemli bulunmuştur. En düşük bin tane ağırlığı 26,89 g ile Ümran Hanım çeşidinde belirlenmiş ve Kızıltan-91 makarnalık buğday çeşidi ile arasındaki farklılık önemli olmamıştır. Yavaş salınımlı azotlu gübre uygulamasında ise en yüksek bin tane ağırlığ $131,56 \mathrm{~g}$ ile Çeşit-1252 çeşidinde belirlenmiş, ancak diğer makarnalık buğday çeşidi (Kızıltan-91) ile arasında önemli bir farklılık bulunmamıştır. Bu gübre formunda tritikale çeşitleri istatistiksel olarak aynı grupta yer almış ve makarnalık buğday çeşitlerine göre daha düşük bin tane ağırlığı elde edilmiştir. En düşük bin tane ağırlığı 27,22 g ile Karma-2000 çeşidinde tespit edilmiştir (Tablo 8).
Çeşitlerin genel ortalaması incelendiğinde en yüksek bin tane ağırlığı değerleri makarnalık buğday çeşitlerinde (Çeşit-1252, 32,67 g; Kızıltan-91, 30,0 g) belirlenmiştir. Tritikale çeşitlerinde ise bin tane ağırlığ önemli seviyede düşük bulunmuştur (Ümran Hanım, 27,39 g; Karma-2000, 28,39 g). Tritikaledeki tane buruşukluğu bin tane ağırlığının azalmasına neden olmaktadır (Tablo 8).

Bin tane ağırlı̆̆ özelliktir. Bin tane ağırlığının yüksek olması tanenin iri ve endospermin daha dolgun olduğunu göstermektedir. Tritikalede bin tane ağırlığı ilgili yapılan çalışmalarda; Akgün ve ark. [48] 35,3-47,5 g, Kılıç ve ark. [49] 30,338,3g, Akgün ve ark.[50] 34,3-46,7 g, Lermi ve Palta [51] 24,64-35,97 $\mathrm{g}$ arasında değiștiğini bildirmişlerdir. Makarnalık buğday çalışmalarında bin tane ağırlığı; Yılmaz ve Dokuyucu [52] 33,7-44,9 g, Kılıç ve ark.[49] 30,3-38,3 g, Kendal ve ark. [53] 30,0-42,8 g arasında değişim gösterdiğini belirlemişlerdir. Bu araştırmada tam olum dönemindeki hasat değerleri incelendiğinde tritikalede ve makarnalık buğdayda elde edilen sonuçların diğer araştırma sonuçlarına benzer olduğu görülmektedir. Ozkaya et al. [17] tarafindan makarnalık buğday çeşitleri üzerinde yapılan çalışmada, çiçeklenmeden tam oluma kadar geçen sürelerde (3 gün aralıklarla 6 örnekleme), firik örnek materyallerin fiziksel özellikleri incelenmiştir. Olgunlaşma zamanı ilerledikçe bin tane ağırlığı düzenli ve önemli ölçüde artmıştır. 
Akgün ve Ulupınar [24] tarafindan farklı makarnalık buğday çeşitleri kullanılarak yapılan çalışmada, azot dozlarına göre ortalama bin tane ağıllığ $139,05-46,30 \mathrm{~g}$ arasında değişmiş ve çeşit $\times$ azot interaksiyonu istatistiksel olarak önemli bulunmuştur. Araştırıcılar azotlu gübrelemenin etkisinin çeșide göre değiștiğini bildirmişlerdir. Benzer sonuçlar farklı araştırmalarda da belirlenmiştir [54, 55]. Diğer taraftan, azot dozlarının 1000 tane ağırlı̆ı̆ını etkilemediği, yüksek azot dozların ise bin tane ağırllğında azalmaya neden olduğu tespit edilmiştir [56]. Yine farklı araştırıcılar tarafindan yüksek azot dozlarının 1000 tane ağırlığını azalttığı saptamıştır [57, 58]. Kızıltan-91 buğday çeşidi kullanılarak yapılan çalışmada, 8 ve $14 \mathrm{~kg} \mathrm{da}^{-1}$ azotlu gübre uygulamasının 1000 tane ağırlı̆̆ı üzerine önemli bir etkisinin olmadığı bildirilmiştir [59]. Yavaş ayrışan gübreler uzun zamanlı etki sağlayabilmektedir. Tejada et al. [29] yavaş ayrışan gübre uygulamasının; buğdayda 1000 dane ağırlığını $\% 3,9$ oranında arttırdığını ileri sürmüşlerdir.

Araştırmada, çeşit $\mathrm{x}$ gübre interaksiyonu önemli bulunmuş ve bu durum çeşitlerin azot kullanım etkisinin farklı olması, kardeşlenme yeteneği, veya çevre şartlarına bağlı olarak olgunlaşma zamanlarının değișebilmesi ile ilișkili olabilir. Nitekim Çeşit-1252 ve Karma-2000 tüm hasat dönemlerinde NP33 gübresinin azotunu daha hızlı kullandığı, Kızıltan-91 ve Ümran Hanım çeșitleri ise yavaş salınımlı gübreyi daha etkin kullanmış olduğu görülmektedir.

\subsection{Hektolitre Ağırlığı}

Hektolitre ağırlığı hasat zamanlarına göre önemli farklılık göstermiştir $(\mathrm{P} \leq 0,01)$ ve ortalamalar Tablo 9'da verilmiştir. Ortalama hektolitre ağırlığında, en düşük değer $(72,42 \mathrm{~kg}) 1$. hasat zamanında, en yüksek değer ise tam olum döneminde $(78,67 \mathrm{~kg})$ elde edilmiştir. Çalışmada çeşit $\times$ gübre $\times$ hasat interaksiyonu önemli bulunmuştur $(\mathrm{P} \leq 0,05)$. En yüksek hektolitre ağırlığı tüm hasat zamanlarında ve gübre çeşitlerinde $84,33 \mathrm{~kg}$ ile Çeşit-1252 çeşidinde elde edilmiştir. Diğer çeşitlerde hasat zamanlarına ve gübre çeşitlerine göre hektolitre ağırlığında farklı değerler elde edilmiştir. $\mathrm{Bu}$ durum çeşitlerin azot kullanım etkisinin farklı olması, kardeşlenme yeteneği veya olgunlaşma zamanları ile ilişkili olabileceği düşünülmektedir (Tablo 9). Bin tane ağırlığında olduğu gibi, tüm çeşitlerde olgunlaşmanın ilerlemesine bağlı olarak, tanedeki nişasta birikiminin artması, hektolitre ağırlı̆̆ da arttırmıştır. Erken dönemde yapılan hasatlarda hektolitre ağırlığı daha düşük bulunmuştur.

Tablo 9.. Farklı dönemlerinde hasat edilen ve azotlu gübre uygulanan makarnalık buğday ve tritikale çeşitlerinin hektolitre ağırlığına (kg) ilişkin ortalamalar

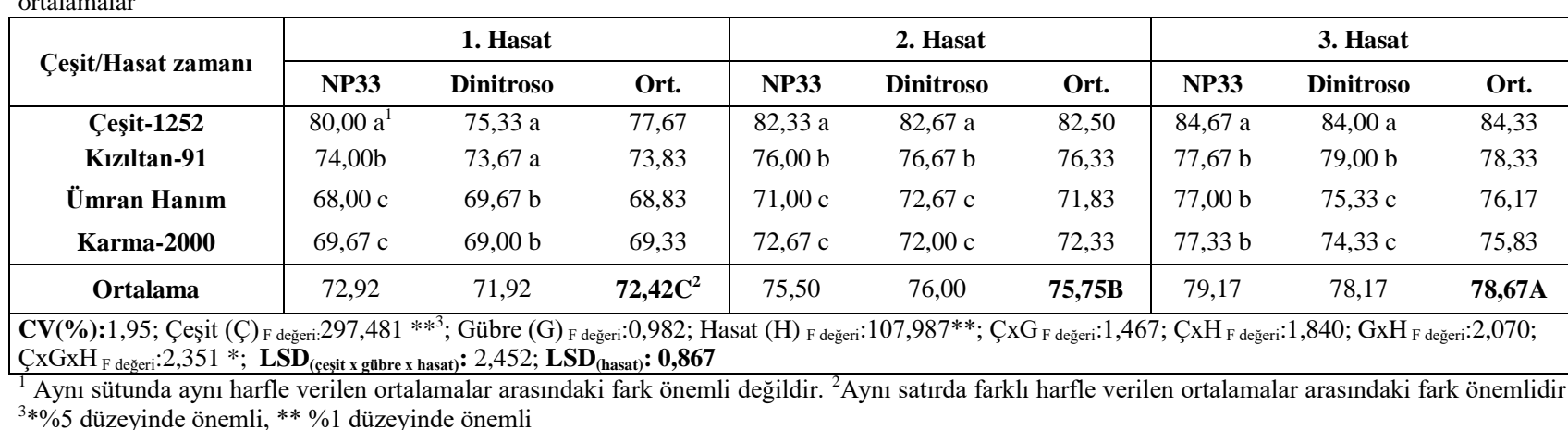

Gübre çeşitlerine göre genel ortalama olarak hektolitre ağırlığı NP33'de 75,86 kg, Dinitroso gübre çeşidinde ise $75,36 \mathrm{~kg}$ olarak belirlenmiş ve istatistiksel olarak gübre çeşitleri arasında fark bulunmamıştır (Tablo 10).

Tablo 10. Makarnalık buğday ve tritikale çeşitlerinde hektolitre ağırlığına (g) ilişkin çeşit x gübre interaksiyonuna ait ortalamalar

\begin{tabular}{lccc}
\hline Çeşit/Gübre & NP33 & Dinitroso & Ortalama \\
\hline Çeşit-1252 & 82,33 & 80,67 & $81,50 \mathrm{~A}$ \\
Kızıltan-91 & 75,89 & 76,44 & $76,17 \mathrm{~B}$ \\
Ümran Hanım & 72,00 & 72,56 & $72,28 \mathrm{C}$ \\
Karma-2000 & 73,22 & 71,78 & $72,50 \mathrm{C}$ \\
\hline Ortalama & 75,86 & 75,36 & \\
\hline LSD & & & \\
\hline *Aynșit) 1,164 & & \\
değitunda aynı harfle verilen ortalamalar arasındaki fark önemli
\end{tabular}

Çeşitlere göre hektolitre ağırlığı önemli farklılık göstermiş ve ortalama değerler Tablo 10'da verilmiştir. Tritikale çeşitlerinin hektolitre ağırlığı, makarnalık buğday çeşitlerine göre önemli seviyede daha düşük bulunmuştur. En yüksek hektolitre ağırlığı 81,50 kg ile Çeşit-1252'de belirlenmiş ve bu çeşit ile diğerleri arasındaki farklılık önemli olmuştur. Tritikale çeşitleri istatistiksel olarak aynı grupta yer almıştır (Tablo 10).

Hektolitre ağırlığı; kabuk yüzeyinin azlığı ve un randımanı fazla olması ilişkili bir özelliktir Tritikale üzerinde yapılan çalışmalarda hektolitre ağırlığı; Akgün ve ark. [22] 67,2-73,8 kg, Çiftçi ve ark [60] $66,11-72,57 \mathrm{~kg}$, Kızılgeçi ve Yıldırım [61] 73,13-79,50 $\mathrm{kg}$, Mut ve Köse [42] 66,7-71,3 kg arasında değiștiğini bildirmişlerdir.

Hektolitre ağırlığının tritikalede buğdaydan düşük olduğu farklı araştırıcılar tarafından belirlenmiştir [62, 61]. Makarnalık buğdayda hektolitre ağırlığı Akgün ve ark. [22] 76,9 kg, Taghouti et al. [63] 78,77-81,66 kg, Türköz ve Mut [64] 73,7-77,0 kg arasında bulmuşlardır. Denemede kullanılan çeşitlerin tam olum döneminde elde ettiğimiz hektolitre ağırlıkları diğer araştırmalar ile paralellik göstermektedir. Yine erken 
hasat döneminde hektolitre ağırlığının düşük olduğu Ozkaya et al. [17] tarafından yapılan çalışmada da belirlenmiştir. Araştırıcılar çiçeklenmeden sonra 3'er gün aralıklarla alınan makarnalık buğday örneklerde (6 örnekleme zamanı) çeşitlere göre hektolitre ağırlığ1 46,6-82,8 kg arasında değișmiştir. Tohum olgunlaşmasına bağlı olarak hektolitre ağırlığı artmıştır.

\subsection{Tane Verimi}

Araştırmada tane verimi üzerine çeşidin ve hasat zamanının etkisi önemli bulunmuştur $(\mathrm{P} \leq 0,01)$. Farklı tane olum dönemlerinde makarnalık buğday (Çeşit1252 ve Kızıltan-91) ve tritikale (Ümran Hanım ve Karma-2000) çeşitlerinin tane verimi değişiklik gösterdiğinden çeşit $\times$ hasat interaksiyonu da istatistiki olarak önemli olmuştur $(\mathrm{P} \leq 0,01$; Tablo 10). Genel ortalamalara göre en düşük tane verimi 1. Hasat döneminde $\left(173,05 \mathrm{~kg} \mathrm{da}^{-1}\right)$, en yüksek değer $(287,47$ $\mathrm{kg} \mathrm{da}^{-1}$ ) ise tam olum döneminde belirlenmiștir. Tüm olum dönemlerinde Ümran Hanım çeşidinden en düşük tane verimi elde edilmiştir (1. hasat $137,20 \mathrm{~kg} \mathrm{da}^{-1} ; 2$. hasat $188,00 \mathrm{~kg} \mathrm{da}^{-1} ; 3$. hasat $226,71 \mathrm{~kg} \mathrm{da}^{-1}$ ). Erken yapılan hasatlarda tane verimi yönünden makarnalık buğday çeşitleri ile Karma -2000 arasındaki fark önemli olmadığı halde, tam olum döneminde makarnalık buğday çeşitlerinde tane verimi, tritikale çeşitlerinden daha fazla bulunmuş ve bu farklılık istatistiksel olarak önemli olmuştur (Tablo 11). Tam olum döneminde en fazla tane verimi Çeşit-1252'de $\left(356,81 \mathrm{~kg} \mathrm{da}^{-1}\right)$ belirlenmiştir. Araştırmada gübre $\times$ hasat intereksiyonu önemli olmamış, ancak firik amacıyla erken hasat dönemlerinde Çeşit-1252 ve Ümran Hanım çeşitlerinde NP33 uygulamasında, Kızıltan-91'de ise Dinitrosa uygulamasında daha yüksek değerler elde edilmiştir.

Tablo 11. Farklı dönemlerinde hasat edilen ve azotlu gübre uygulanan makarnalık buğday ve tritikale çeşitlerinin tane verimine (kg da ${ }^{-1}$ ) ilişkin ortalamalar

\begin{tabular}{|c|c|c|c|c|c|c|c|c|c|}
\hline \multirow{2}{*}{ Çeşit/Hasat zamanı } & \multicolumn{3}{|c|}{ 1. Hasat } & \multicolumn{3}{|c|}{ 2. Hasat } & \multicolumn{3}{|c|}{ 3. Hasat } \\
\hline & NP33 & Dinitroso & Ort. & NP33 & Dinitroso & Ort. & NP33 & Dinitroso & Ort. \\
\hline Çeşit-1252 & 226,47 & 160,27 & $193,37 \mathrm{a}^{1}$ & 272,88 & 228,72 & $250,80 \mathrm{a}$ & 369,03 & 344,59 & $356,81 \mathrm{a}$ \\
\hline Kızıltan-91 & 173,78 & 175,42 & $174,59 \mathrm{a}$ & 236,36 & 254,37 & $245,37 \mathrm{a}$ & 313,26 & 300,70 & $306,98 b$ \\
\hline Ümran Hanım & 137,37 & 137,04 & $137,20 \mathrm{~b}$ & 192,96 & 183,05 & $188,00 \mathrm{~b}$ & 206,31 & 247,12 & $226,71 d$ \\
\hline Karma-2000 & 190,50 & 183,58 & $187,04 \mathrm{a}$ & 229,14 & 255,41 & $242,27 \mathrm{a}$ & 251,25 & 267,46 & $259,35 \mathrm{c}$ \\
\hline Ortalama & 182,03 & 164,08 & $173,05 C^{2}$ & 232,84 & 230,39 & 231,61B & 284,96 & 289,97 & $287,47 A$ \\
\hline $\begin{array}{l}\mathbf{C V}(\%): 9,15 ; \text { Çeşit (Ç) } \\
1,846 ; \text { ÇxGxH F değeri } 1,2\end{array}$ & $\begin{array}{l}\text { ri: } 17,31 \\
\text { LSD }_{\text {(has }}\end{array}$ & 12,418; LSI & $\begin{array}{l}\text { eğeri: } 0,959 ; \\
\text { x hasat) }: \mathbf{2 4 , 8}\end{array}$ & & & & & & $\mathrm{GxH}_{\mathrm{F} \text { değeri }}:$ \\
\hline
\end{tabular}

Tablo 11' de görüldüğü gibi, gübre çeşitlerinin etkisi önemsiz bulunmasına rağmen, çeşit $x$ gübre interaksiyonu önemli bulunmuş $(\mathrm{P} \leq 0,05$; Tablo 11) ve ortalamalar Tablo 12'de verilmiștir.

Tablo 12. Makarnalık buğday ve tritikale çeşitlerinde tane verimine $(\mathrm{kg} / \mathrm{da})$ ilişkin çeşit x gübre interaksiyonuna ait ortalamalar

\begin{tabular}{lccc}
\hline Çeşit/Gübre & NP33 & Dinitroso & Ortalama \\
\hline Çeşit-1252 & $289,46 \mathrm{~A}^{1}$ & $244,53 \mathrm{~A}$ & $266,99 \mathrm{~A}$ \\
Kızıltan-91 & $241,13 \mathrm{~B}$ & $243,49 \mathrm{~A}$ & $242,32 \mathrm{AB}$ \\
Ümran Hanım & $178,88 \mathrm{C}$ & $189,07 \mathrm{~B}$ & $183,97 \mathrm{C}$ \\
Karma-2000 & $223,63 \mathrm{~B}$ & $235,48 \mathrm{~A}$ & $229,56 \mathrm{~B}$ \\
\hline Ortalama & 233,28 & 228,14 & 230,71 \\
\hline
\end{tabular}

LSD $_{\text {(cesit) }}$ : 28,952; LSD $_{\text {(cesit x gübre ) }}$ :24,172

${ }^{1}$ Aynı sütunda aynı harfle verilen ortalamalar arasındaki fark önemli değildir.

NP33 gübre uygulamasında en yüksek tane verimi Çeşit-1252'den elde edilmiş (289,46 kg/da), en düşük ise Ümran Hanım tritikale çeşidinde belirlenmiştir. Dinitroso gübre uygulamasında ise Çeşit-1252 (244,53 kg da $\left.{ }^{-1}\right)$, Kizıltan-91 (243,49 $\left.\mathrm{kg} \mathrm{da}^{-1}\right)$ ve Karma-2000 $\left(235,48 \mathrm{~kg} \mathrm{da}{ }^{-1}\right)$ çeşitleri tane verimi yönünden istatistiksel olarak aynı grupta yer almıştır. $\mathrm{Bu}$ veriler Karma-2000 ve Kızıltan-91 çeşitlerinin yavaş salınımlı gübreden daha fazla yararlandıklarını göstermektedir. Çeşitlerin genel ortalaması incelendiğinde, makarnalık buğday çeşitlerinin tane verimi, tritikale çeşitlerinden daha fazla bulunmuştur (Tablo 12).
Yapılan çalışmalarda tritikalede tane verimi; Akgün ve ark [22] 229,5 -357,1 kg da ${ }^{-1}$, Geren ve ark [65] 157$539 \mathrm{~kg} \mathrm{da}^{-1}$, Tayyar ve Kahrıman [66] 277,9- 367,1 kg $\mathrm{da}^{-1}$, Mut ve Köse [42] 230,4-366,1 kg da ${ }^{-1}$ arasında bulunmuştur. Makarnalık buğdayda ise tane veriminin Aydoğan ve ark. [67] 343,73-517,26 kg da ${ }^{-1}$; Türköz ve Mut [64] 202,70-367,92 kg da ${ }^{-1}$; Ulupınar [68] 294,60$396,90 \mathrm{~kg} \mathrm{da}{ }^{-1}$; arasında değiștiği belirlenmiştir. Araştırıcılar hem tritikalede hem de makarnalık buğdayda tane verimi yönünden çeşitler arasında önemli farklılıkların olduğunu, ekolojik şartların ve kültürel uygulamaların tane verimini etkilediğini bildirmişlerdir. Tane verimi ile azotlu gübreleme arasında pozitif bir ilişkinin bulunduğunu belirlemiştir [54, 56]. Yapılan çalıșmalarda çevresel koșulları ve gübre uygulamalarının tane verimi ve tanenin fiziksel özellikleri üzerinde önemli etkiye sahip olduğunu bildirmiştir $[69,70]$.

Tahıl çeşitlerinde genel olarak tane verimi ve protein içeriği arasında negatif korelasyon bulunmaktadır. $\mathrm{Bu}$ negatif korelasyon bir çok çalışmada ortaya konulmuştur [71, 72]. Nitekim benzer sonuçlar bu çalışmada da belirlenmiş, yüksek verimli Çeşit-1252 ve Kızıltan-91 çeşitlerinde protein oranı, tritikale çeşitlerinden daha düşük bulunmuştur (Tablo 3). 


\section{SONUÇ}

Firik elde etmek amacıyla, hasatın doğru zamanını belirlemek kritik öneme sahiptir. Başaklar çok erken hasat edilip ve kavrulduğunda taneler çok küçülmekte, çok geç hasat edildiğinde ise firikin kendine özgü yeşil rengini ve lezzetini kaybetmektedir. Araştırmada, tanedeki su oranı, protein içeriği, bin tane ağırlığına, hektolitre ağırlığı ve tane verimi değerleri incelendiğinde, makarnalık buğday ve tritikalenin firik amacıyla kullanımında sert hamur olum döneminde (2. hasat) hasadının uygun olduğu belirlenmiştir. Yavaş salınımlı gübre uygulaması tüm çeşitlerde protein oranı ve tanedeki mineral madde zenginliği ile ilișkili olan kül oranını arttırmış olmasına rağmen, bin tane ağırlığı, hektolitre ağırlığı ve tane verimi üzerine etkisi önemsiz bulunmuştur. Ancak tane veriminde çeşit $\mathrm{x}$ gübre interaksiyonunun önemli olduğu ve Çeşit-1252 hariç, araştırmada kullanılan diğer çeşitlerde Dinitroso uygulamasında daha fazla tane verimi elde edilmiştir. $\mathrm{Bu}$ sonuçlar yavaş salınımlı gübrelerin bitki gelişmesinde etkin olduğunu göstermektedir.

Genel ortalama olarak tritikale çeşitlerinde, makarnalık buğdaya göre daha yüksek protein ve kül oranı elde edilmiștir. Bu nedenle tritikalenin erken hasat ile firik olarak insan beslenmesinde kullanılabileceği düşünülmektedir.

\section{Teșekkür}

2019 YL-0034 No`lu Proje ile bu çalışmayı maddi olarak destekleyen Isparta Uygulamalı Bilimler Üniversitesi Bilimsel Araştırma Projeleri Yönetim Birimine teşekkür ederiz.

\section{KAYNAKLAR}

[1] Anonim 2019. Türkiye İstatistik Kurumu. http://biruni.tuik.gov.tr/medas/?kn = 92\&locale $=$ tr. $($ Erișim Tarihi: 26.10.2020).

[2] USDA 2020. Grain and feed update https://apps.fas.usda.gov/newgainapi/api/Report/ DownloadReportByFileName?fileName $=$ Grain $\%$ 20and\%20Feed\%20Update_Ankara_Turkey_0130-2019. Erișim tarihi 21.10.2020.

[3] Gregory RS. Commercial production of triticale. Span. 1975;18(2), 65-66.

[4] Akgün İ, Kara B. Alternatif bir yembitkisi tritikale. S.D.U. Fen Bil. Enst. Dergisi. 2002;6(3): 68-75.

[5] Kochetova A, Levitskii A, Federova T. Tritikale. Nutr. Abst. 1987;57(3), 936 p.124.

[6] Raun WR, Johnson GV. Improving nitrogen use efficiency for careal production. Agronomy Journal. 1999;91:357-363.

[7] Mukherjee A, Sinha I, Das R. Application of nanotechnology in agriculture: Future prospects. Outstanding Young Chemical Engineers (OYCE) Conference, March 13-14. 2015. DJ Sanghvi College of Engineering, Mumbai, India.

[8] Vallega V. The quality of Triticum monococcum L. in perspective. Pages 129-146 in: Hulled
Wheats. S. Padulosi, K. Hammer, and J. Heller, eds.1996. IPGRI Press, Rome, Italy.

[9] Williams PC, El-Haremein FJ. Frekeh making in Syria. A Small but significant local industry. Rachis. 1985;3(2), 28-30

[10] Fowler DB, Brydon J, Baker RJ. Nitrogen fertilization of no-till winter wheat and rye. II. Influence on Grain Protein. Agronomy Journal. 1989;81,72-77.

[11] Yılmaz MF. Kahramanmaraș koşullarında II. ürün mısır bitkisinde (Zea mays 1.) farklı sıra üzeri mesafeler ve azot dozlarının verim ve verim unsurları ile tohum kalitesine etkisi. Yüksek lisans tezi, Kahramanmaraş Sütçü İmam Üniversitesi, Fen Bilimleri Enstitüsü; 2005.

[12] Elgün A, Ertugay Z, Certal, M, Kotancılar HG. Tahıl ve ürünlerinde analitik kalite kontrolü ve laboratuvar uygulama klavuzu. Atatürk Üniversitesi Yayın No: 867, Ziraat Fakültesi Yayın No: 335, Ders Kitapları Serisi No: 82. 1998;238s.

[13] Carsanba E, Akca İ, Timur M. Examination of firik produced in hatay region in terms of nutritional aspect. GIDA the Journal of Food. 2017;42(6),726-730.

[14] Hamit MA., Omari MAA. Study of automatization of frekeh industry in Jordan. Dirasat. 1986;13,31-50.

[15] Musselman LJ, Mouslem AB. Frikeh, Roasted green wheat. Econ Bot. 2001;55(2),187-189.

[16] Dick JW, Matsuo RR. Durum wheat and pasta products. In Y. Pomeranz (Ed.), Wheat Chemistry and Technology. St. Paul, MN: Am. Assoc. Cereal Chem. American Assoc. Cereal Chem. 1988;2, pp. 507-547.

[17] Ozkaya B, Ozkaya H, Eren N, Unsal AS, Koksel $\mathrm{H}$. Effects of wheat maturation stage and cooking method on physical and chemical properties of firiks. Food Chem. 1999;66(1), 97-102.

[18] Al-Mahasneh M, Rababah T. Effect of moisture content on some physical properties of green wheat. Journal of Food Engineering. 2007;79,1467-1473, Jordan.

[19] Durmaz AH. Yavaş ayrışan gübre ve yaprak gübresi uygulamasının ayçiçeği bitkisinin verim ve yağ kalitesi üzerine etkilerinin araştırılması. Yüksek lisans tezi, Namık Kemal Üniversitesi, Fen Bilimleri Enstitüsü; 2012.

[20] Feil B., Fossati D. Mineral composition of triticale grains as related to grain yield and grain protein. Crop. Sci. 1995;35,1426-1431.

[21] Atak M, Çiftçi CY. Bazı tritikale çeşit ve hatlarının morfolojik karakterizasyonu. Ankara Üniversitesi Ziraat Fakültesi, Tarım Bilimleri Dergisi. 2006;12 (1), 101-111.

[22] Akgün İ, Kaya M, Altındal D. Isparta ekolojik koşullarında bazı tritikale hat/çeşitlerinin verim ve verim unsurlarının belirlenmesi. Akdeniz Üniversitesi Ziraat Fakültesi Dergisi. 2007;20(2),171-182.

[23] Haile D, Nigussie D, Ayana A. nitrogen use efficiency of bread wheat: effects of nitrogen rate 
and time of application. Journal of Soil Science and Plant Nutrition. 2012;12(3), 389-410.

[24] Akgün İ, Ulupınar Ü. The effect of nitrogen dosage applications on yield and quality in durum wheat (Triticum durum Desf.) Turkish Journal of Agriculture - Food Science and Technology. 2019;7(2),72-81.

[25] Guertal EA. Slow-release nitrogen fertilizers in vegetable production: A Review. HortTechnology. January-March 2009;19(1).

[26] Richards JE, Daigle JY, LeBlanc P, Paulin R, Ghanem I. nitrogen availability and nitrate leaching from organomineral fertilizers, Canadian Journal of Soil Science. 1993;73(2), 197-208.

[27] Tejada M, Benitez C., Gonzalez JL. Nitrogen mineralization in soil with conventional and organomineral feritlization practices, Communications in Soil Science and Plant Analysis. 2002;33(19/20), 3679-3702.

[28] Blagoveshchenskaya GG, Burlakova LY, Zavalin AA, Zyabkina GA, Merzlaya GE, Dyshko VI. Stability of agrocenoses during long-term use of organic and mineral fertilizers. Russian Agricultural Sciences $\mathrm{C} / \mathrm{C}$ Of DokladyRossiiskaia Akademiia Sel'skokhoziaistvennykh Nauk. 2005;12: 14.

[29] Tejada M, Benitez C, Gozalez JL. Effects of application of two organomineral fertilizers on nutrient leaching losses and wheat crop, Agronomy Journal. 2005;97, 960-967.

[30] D'Edigio MG, Cecchini C. Immature wheat grains as functional foods. Italian Food and Beverage Technology. 1998;14: 34.

[31] Humphries JM, Khachik F. distribution of lutein, zeaxanthin, and related geometrical isomers in fruit, vegetables, wheat, and pasta products. J Agric Food Chem. 2003;51(5), 1322-1327.

[32] Bird AR, Mular M. Product analysis: Green wheat freekeh. CSIRO Health Sciences and Nutrition, Product analysis report. 2003;p. 4.

[33] Aydın F, Koçak AN, Dağ A. Bazı buğday çeşitlerinin bulgur kalitesinin belirlenmesi üzerine bir araştırma. Makarnalık Buğday ve Mamulleri Sempozyumu, 30 Kasım-3 Aralık 1993, Ankara, 310-315.

[34] Budak H, Karaltın S. Bazı makarnalık buğday çeşitlerinin fiziksel ve kimyasal yöntemlerle kalite özelliklerinin belirlenmesi. Anadolu, J. of Aari. 1998;8(2), 66-79.

[35] Bulut S. Ekmeklik buğdayda kalite. Erciyes Üniversitesi Fen Bilimleri Enstitüsü Dergisi. 2012;28:441-446.

[36] Misra SC, Shinde S, Geerts S, Rao VS, Monneveux P. Can Carbon isotope discrimination and ash content predict grain yield and water use efficiency in wheat. Agricultural Water Management. 2010;97,57-65.

[37] Garrido-Lestache E, Lopez-Bellido RJ, LopezBellido L. Durum wheat quality under mediterranean conditions as affected by $\mathrm{N}$ rate, timing and splitting, $\mathrm{N}$ form and $\mathrm{S}$ fertilization. European Journal of Agronomy. 2005;23(3),265278.
[38] Menteş-Yılmaz Ö. Türkiye'de yetiştirilen başlıca buğday çeşitlerinin antioksidan akitivitelerinin ve fenolik asit dağılımlarının belirlenmesi ve ekmeğin nar kabuğu ekstratı ile zenginleştirilmesi. Ankara Üniversitesi Fen Bilimleri Enstitüsü, Doktora Tezi, 89 sayfa, Ankara; 2011.

[39] Anonim 2016. Buğdayların özellik açısından karşılaştırılması. T.C Kastamonu Valiliği İl Gıda Tarım ve Hayvancılı Müdürlüğü. https://kastamonu.tarim.gov.tr/ (Erişim Tarihi: 10.9.2020).

[40] Ünal SS. Buğdayda kalitenin önemi ve belirlenmesinde kullanılan yöntemler. Hububat 2002. Hububat Ürünleri Teknolojisi Kongre ve Sergisi. 3-4 Ekim 2002. Gaziantep, 2002;25-37.

[41] Leon AE, Rubiolo A, Anon MC. Use of triticale flours in cookies: Quality Factors Cereal Chem. 1996;73(6),779-784.

[42] Mut Z, Erbaş Köse ÖD. Tritikale Genotiplerinin tane verimi ve bazı kalite özellikleri. Bozok Üniversitesi Ziraat Fakültesi, Anadolu Tarım Bilimleri Dergisi. 2018;33,47-57. doi: 10.7161/omuanajas.336108.

[43] Haghayegh G, Schoenlechner R. Comparison of functional properties of isolated emmer and einkorn wheat starches. J Food Agric Environ. 2010;8, 239-243.

[44] Yaraşır N. farklı dozlarda sıvı biyogaz atıklarının buğday (Triticum aestivum L.) bitkisinde verim ve kalite üzerine etkisi. Adnan Menderes Üniversitesi Fen Bilimleri Enstitüsü, Yüksek Lisans Tezi, 75 sayfa, Aydın; 2018.

[45] Ayoub M, Guertin S, Fregeau-Reid J, Smith DL. Nitrogen fertilizer effect on breadmaking quality of hard red spring wheat in eastern canada. Crop. Sci. 1994;34, 1346-1352.

[46] Aksu T. Farklı azot ve çiftlik gübre dozlarının ekmeklik buğdayda verim, kalite ve antioksidan aktivitesi üzerine etkisi. Yüksek Lisans Tezi, Adnan Menderes Üniversitesi, Fen Bilimleri Enstitüsü, Aydın; 2017.

[47] Dexter JE, Crowle WL, Matsuo RR, Kosmolak FG. Effect of nitrogen fertilization on the quality characteristics of five north american amber durum wheat cultivars. Canadian Journal of Plant Science. 1982;62, 901-912.

[48] Akgün İ, Tosun M, Sağsöz S. Erzurum ekolojik koşullarında bazı tritikale hat ve çeşitlerinin verim ve verim unsurları üzerine bir araştırma. Atatürk Üniversitesi Ziraat Fakültesi Dergisi. 1997;28(1),103-119.

[49] Kılıç H, Dönmez E, Yazar S, Şanal T, Altıkat A. Elazığ ve Malatya şartlarına uygun makarnalık buğday çeşitlerinin belirlenmesi. Bitkisel Araştırma Dergisi. 2007;2, 6-13.

[50] Akgün İ, Kaya M, Altındalı D. Isparta ekolojik koşullarında bazı tritikale hat/çeşitlerinin verim ve verim unsurlarının belirlenmesi. Akdeniz Üniversitesi Ziraat Fakültesi Dergisi. 2008;20(2),171-182.

[51] Lermi AG, Palta Ş. Batı Karadeniz ekolojisinde farklı tritikale (Xtriticosecale Wittmack) 
çeșitlerinin tohum verimi üzerine araștırma. Bartın Orman Fakültesi Dergisi. 2018;20 (2), 366372.

[52] Yılmaz HA, Dokuyucu T. Kahramanmaraş koşullarına uygun ve yüksek verimli makarnalık buğday çeşitlerinin saptanması. Tarla Bitkileri Kongresi, 25-29 Nisan 1994, İzmir, 1, 9-12.

[53] Kendal E, Tekdal S, Aktaş H, Altıkat A, Karaman M, Baran İ. Diyarbakır ekolojik koşullarına uygun yabancı yazlık makarnalık buğday çeşitlerinin belirlenmesi. Türkiye VIII. Tarla Bitkileri Tarım Kongresi. 12-25/09.2011, Bursa. 242-245.

[54] Ottman MJ, Doerge TA, Martin EC. Durum grain quality as affected by nitrogen fertilization near anthesis and irrigation during grain fill. Agronomy Journal. 2000;92.5: 1035-1041.

[55] Acer S. Bazı makarnalık buğday çeşitlerinin verim ve kalite özellikleri üzerine farklı sulama zamanları ile azot dozlarının etkisi. Doktora Tezi, Ankara Üniversitesi, Fen Bilimleri Enstitüsü; 2004.

[56] Çiftçi AE, Doğan R. Azotlu gübre dozlarının Gediz-75 ve Flamura-85 buğday çeşitlerinde verim ve kaliteye etkisi. Tarım Bilimleri Dergisi. 2013;19(1), 1-11.

[57] Guohua M, Tang L, Zhang F, Zhang J. Carbonhydrate storage and utilization during grain filling as regulated by nitrogen application in two wheat cultivars. Journal of Plant Nutrition. 2002;25(2), 213-229.

[58] Özseven İ, Bayram EM. Marmara Bölgesinde dört ekmeklik buğday (Triticum aestivum var. aestivum L.) çeşidinde değişik azot dozlarının verim ve verim unsurlarına etkilerinin araştırılması. Tarla Bitkileri Merkez Araştırma Enstitüsü Dergisi. 2005;14, 1-2.

[59] Altuntaş A, Akgün İ. Uşak koşullarında Kızıltan91 buğday çeşidi üzerinde farklı azot dozu ve sıv1 gübre uygulamalarının verim ve verim unsurlarına etkisi. Süleyman Demirel Üniversitesi, Fen Bilimleri Enstitüsü Dergisi. 2016;20(3), 496-503.

[60] Çiftçi AE, Kınabaş S, Yelbey S, Yağdı K. Bazı tritikale hatlarının kalite özellikleri ve ekmek yapımında kullanılma olanaklarının araştırılması. Uludağ Üniversitesi Ziraat Fakültesi Dergisi. 2010;24(2), 93-102.

[61] Kızılgeçi F, Yıldırım M. Bazı tritikale ( $X$ Triticosecale Wittmack) genotiplerinin verim ve kalite özelliklerinin belirlenmesi. Turk J Agric Res. 2017;4(1), 43-49.

[62] Tosun M, Akgün İ, Sağsöz S, Taşpınar M. Yazlık ekilen tritikale genotiplerinde verim ve verim ögelerinin belirlenmesi. Atatürk Üniversitesi Ziraat Fakültesi Dergisi. 2000;31 (1), 1-10.

[63] Taghouti M, Gaboun F, Nsarellah N, Rhrib R, ElHaila M, Kamar M, et al. Genotype $\mathrm{X}$ environment interaction for quality traits in durum wheat cultivars adapted to different environments. African Journal of Biotechnology. 2010;9(21), 3054-3062.
[64] Türköz M, Mut Z. Konya ekolojisinde bazı makarnalık buğday genotiplerinin verim ve kaltie özelliklerinin belirlenmesi. Selçuk Tarım ve Gıda Bilimleri Dergisi. 2017;31(2),27-36.

[65] Geren H, Soya H, Ünsal R, Kavut YT, Sevim I, Avcioğlu R. Investigations on the grain yield and other yield characteristics of some triticale cultivars grown under Menemen conditions. J. Agric. Fac. Ege Univ. 2012;49(2), 195- 200.

[66] Tayyar S, Kahrıman F. Biga şartlarında yetiştirilen tritikale genotiplerinin verim ve bazı kalite özelliklerinin belirlenmesi. Adnan Menderes Üniversitesi Ziraat Fakültesi Dergisi. 2016;13(2), 23-31.

[67] Aydoğan S, Göçmen Akçacık A, Şahin M, Demir B, Önmez H, Türköz M, et al. Bazı makarnalık buğday çeşitlerinin kalite özelliklerinin belirlenmesi. Tarla Bitkileri Merkez Araștırma Enstitüsü Dergisi. 2012;21 (1), 1-7.

[68] Ulupınar Ü. Isparta koşullarında makarnalık buğday (Triticum durum Desf.) çeşitlerinin adaptasyonu ve farklı azot dozu uygulamalarının verim unsurlarına etkisi. Yüksek Lisans Tezi, Süleyman Demirel Üniversitesi, Fen Bilimleri Enstitüsü; 2017.

[69] Bouacha OD, Nouaigui S, Rezgui S. Effects of N and $\mathrm{K}$ fertilizers on durum wheat quality in different environments. Journal of Cereal Science. 2014;59(1), 9-14.

[70] Kaya Y, Akçura M. Effects of genotype and environment on grain yield and quality traits in bread wheat (Triticum aestivum L.). Food Sci. Technol. Campinas. 2014;34, 386-393.

[71] Fowler DB. Crop nitrogen demand and grain protein concentration of spring and winter wheat. Agronomy Journal. 2003;95, 260-265.

[72] Guarda G, Padovan S, Delogu G. Grain yield, nitrogen-use efficiency and baking quality of old and modern Italian bread-wheat cultivars grown at different nitrogen levels. Europ. J. Agronomy. 2004;21, 181-192. 